UDC 72.012.8(430 Müchen)"652"

https://doi.org/10.18485/ms_zmslu.2021.49.11

Original scientific paper

Ognjen D. Minić*

\title{
RECEPTION OF CLASSICAL ANTIQUITY: A CASE STUDY OF THE MUSIC SALON OF VILLA STUCK IN MUNICH
}

\begin{abstract}
The paper offers an analysis of the mechanisms of incorporating Classical Antique subject matters and motives when shaping the space and interior decoration of the home of Franz von Stuck, a master German artist, a champion of the Munich Art Nouveau, and a professor of the Munich Academy. The music salon of Villa Stuck is the most tangible and indicative example of the significance of Antique topoi reinterpreted in the spirit of the cultural climate in Germany at the end of the $19^{\text {th }}$ and the beginning of the $20^{\text {th }}$ centuries. As a rare combination of the residential area, atelier, and gathering place for Munich's intellectual elite, Villa Stuck is an original invention of Franz von Stuck. It is explicitly marked by formal and conceptual references to ancient Greece and Rome, often present in the rest of Stuck's oeuvre. The Music Salon of Villa Stuck stands out as a fascinating case study for understanding the far-reaching impact and long duration of originally Classical Antique elements until the turn of the $20^{\text {th }}$ century. The core and starting point of the analysis is Stuck's paintings and sculptures incorporated within the Music Salon. In synergy, they form the core of Stuck's perception of the Antique world, and their analysis helps shed some light on the broader issue of cultural role models and adoptions.

KEYWORDS: Franz von Stuck, Villa Stuck, Classical Antiquity, Reception of Antiquity, Music Salon.

Contradictions and controversies featured a great deal the character and the entire opus of Franz von Stuck. In previous researches, Stuck's opus has been interpreted from different viewpoints. The artist's different phases have been viewed from the perspective of researchers' motivation or the leading narrative of stylistic and chronological art progress. However, Stuck's temperament and artistic legacy have always eluded simplistic categorisation. Franz von Stuck was a multimedia artist who was equally successful in the classical subject matters of painting and sculpture and experimental ideas of Secession and Symbolism. At the same time, he was a distinguished professor at the Munich Academy
\end{abstract}

* The University of Belgrade, Faculty of Philosophy, ognjen.minic@gmail.com 
and a modernist innovator, a painter-prince and a proponent of new and modern art movements, an advocate of classical motives and the ideas reinterpreted via colouristic and suggestive experiment. An eccentric nobleman, a painter, a sculptor, an architect, a designer, an illustrator, etc. All those contradictory features of his persona allow different approaches to his biography and art. Nevertheless, despite the artist's flirting with various current philosophical ideas or technical inventions, the Antique element stood out in all phases of his opus. It was a subjective vision of Classical Antiquity as a vital, intuitive, and primal creative energy paradigm. It was shaped under the influence of Stuck's philosophical and artistic viewpoints, comprehension of Antique heritage, and efforts to incorporate Antique references and topoi in the current art scene. The artist's reception of Antiquity is most evident in Villa Stuck in Munich, specifically in the Music Salon. Most explicitly, the Music Salon of Villa Stuck is the peak of Stuck's art marked by his long-standing fascination with Classical Antiquity. At an individual level, the Music Salon is an ambient substitute for the artist's personality, witnessing the conscious formation and presentation of identity shaped mostly according to the Greco-Roman past image. ${ }^{1}$

For a comprehensive analysis of the common thread of Classical Antiquity (or at least its subsequent reception within the $19^{\text {th }}$-century German cultural circle) and Stuck's design of the interior of his villa in Munich, it is necessary to look at several phenomena in science, culture, and art of the period. Therefore, it will be necessary to briefly review the artistic environment and phenomena in Munich as a dominant $19^{\text {th }}$-century art centre, and the basics of the aesthetics of the period within which Stuck was formed. Setting the artist and his artwork in the broader context of the cultural and artistic development is necessary to understand Stuck's affinity for historical and mythological (Antique) subjet matters present throughout his career in one or another form.

We will deal with Stuck's fascination with the archetypes in Classical Antiquity and their support in other disciplines in the following lines. Recent discoveries in philosophy, psychology, musicology, and archaeology reveal the similarity of ideas among intellectuals of different professional backgrounds. In other words, the visualisation of Stuck's artworks and especially the way he designed own creative and contemplative space in the villa fully correspond to the newly discovered features of Classical Antique cultures, which occupied experts' attention and public since the mid- $19^{\text {th }}$ century. As essential stands out the similarity of Stuck's ideas and formal expression with Friedrich Nietzsche's revolutionary thesis on the duality of the Apollonian and the Dionysian. Other similarities between the Antique references incorporated into the interior of Villa Stuck and the progress of scientific studies of Classical Antiquity are reflected in the artist's familiarity and interpretation of Pompeian wall painting discovered by the latest archaeological findings and in the use of total art principles stemming from Wagner's concept of Gesamtkunstwerk. Furthermore, the common thread is visible in the closeness of Stuck's understanding of dancing,

${ }^{1}$ When emulating Classical Antiquity, Franz von Stuck was not limited to a precise period. He reaches for different societies and poetics of Classical Antiquity, stretching from the Archaic to the Classical Age. 
entertainment, theatre, and, above all, music as the quintessence of artistic inspiration with Nietzsche's understanding of Hellenic tragedy.

We shall now consider the elements inherent in classical mythology and Stuck's choice of iconographic narratives to decorate the Music Salon. The special attention is needed for Orpheus and Pan's painted cycles, which illustrate the ideological connection between the presented Antique characters and Dionysus as a constant Stuck's fascination and a personification of sensuality instinct, animal nature, and unrestrained creative ecstasy. With allusions to disguise games, using masks and other decorative elements of ancient Greek theatre in the decoration of the Music Salon, Franz von Stuck highlighted the idea of own Arcadian space which corresponded to the then-prevailing idea of the Dionysian Mysteries as an essence of the collectivist and unconscious (suppressed) tendencies.

Stuck's visualisation of Classical Antique potency, unscrupulous sensuality and primordial, enigmatic, and wild human nature, reveals the ambiguity of understanding Classical Antiquity's era at the break of the $20^{\text {th }}$ century. Hence, Villa Stuck and the Music Room are a useful example of how one of the most prominent European artists of that period shaped and decorated his residence consistent with own understanding of the spirit of Classical Antiquity employing it as a means of presenting his identity, enduring obsessions, and artistic aspirations.

It is first necessary to briefly review Munich's transformation to understand the origins of the artist's deep and long connection with the artistic approach of Classical Antique subject matters. This city unmistakably paved the way for Stuck's artistic development, into one of the most important cultural and art centres in the late $19^{\text {th }}$ century Europe. The Academy of Fine Arts in Munich (Fig. 1) was founded in 1808. Its making and running are closely related to Enlightenment art theory. As was the case with its counterparts in Paris and Vienna, the objective of the Munich Academy was to convey the ideals of beauty and taste, which would refine the people's spirit and customs. Thus, the Munich Academy was an extension of the state, church, and political ideology. Owing to Peter Langer and Peter Cornelius's efforts, a history painting was seen as the top genre at the Academy. In contrast, alternative artistic trends were faced with misunderstanding and resistance at first (ЛЕНЦ, ШРЕДЕР и др. 1988).

However, along with the academic scene, in Munich flourished different ideas about the approach to arts. Many young artists felt limited by the imposed aesthetic dogma of the Academy, and so they were attracted by ideas of Romanticism emphasising a genius' individuality. They pursued individual expression via conscious departure from "lifeless" academic art, subject matters, formats, and artistic practice. Due to the limited number of artworks that could have been exhibited at the annual exhibitions of the Academy, and to present their oeuvre to a broader audience, a group of artists founded the Munich Artists' Association (Münchner Künstlergenossenschaft) in 1868 (FACOS 2009: 181-182). The Association embraced landscape painters, portraitists, genre painters. Hence, the official and respected academic painters looked down on those artworks, regarding them with suspicion. The Munich Artists' Association's great success relied on the carefully designed marketing 


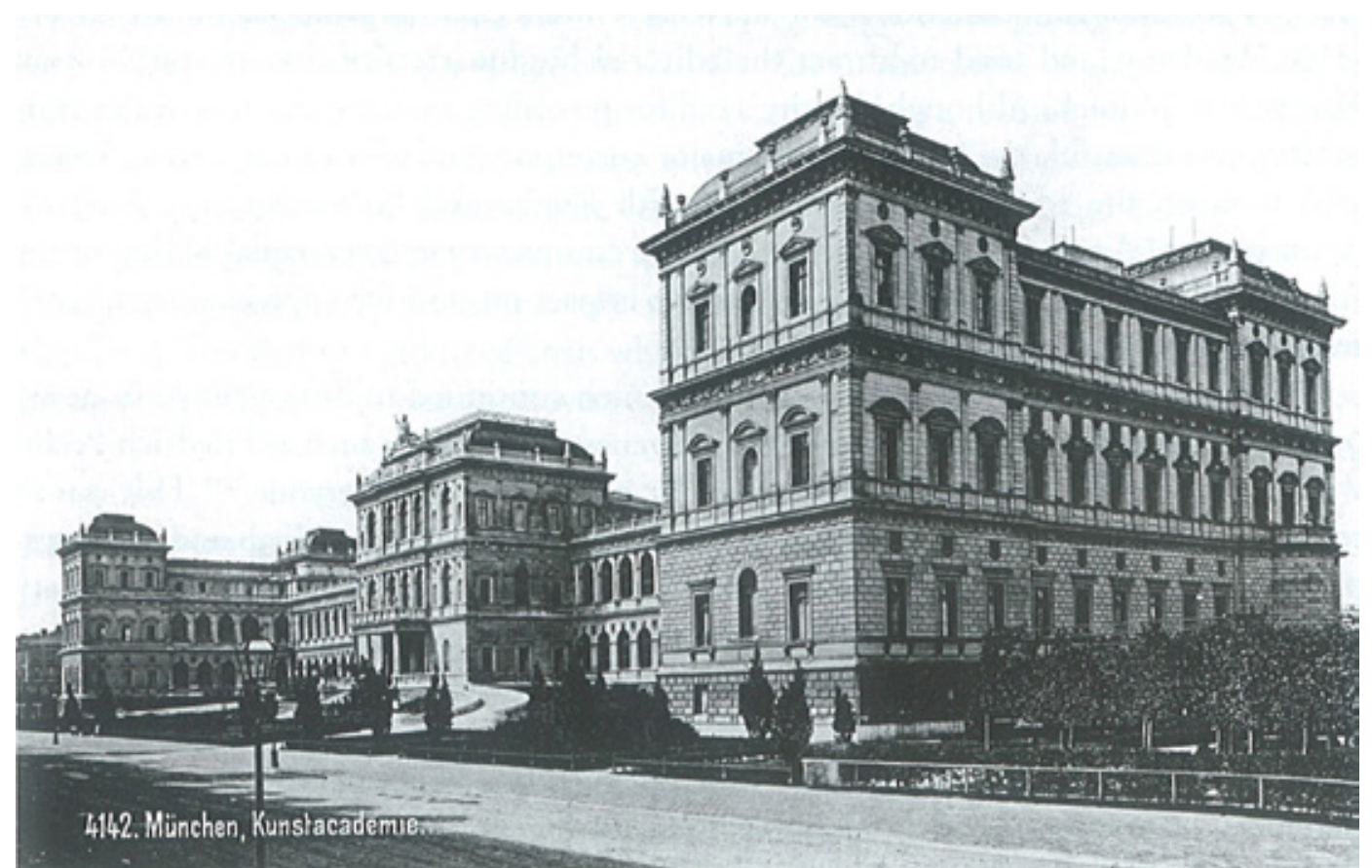

Fig. 1. Royal Academy of Fine Arts in Munich ca. 1890s, photography, source: Fuhrmeister,

Christian, Hubertus Kohle, Veerle Thielemans (ed.). American Artists in Munich - Artistic Migration and Cultural Exchange Processes, Berlin, Munchen: Deutscher Kunstverlag, 2007, 36.

strategy, employment of various subject matters, and stylistic eclecticism, which further triggered the international interest in the Bavarian capital's cultural and artistic events.

Stylistic diversity and Munich artists' pursuits for alternative expressions created the ground for another leading $19^{\text {th }}$-century art movement - the Munich counterpart of Art Nouveau or Jugendstil founded in 1892 whose representatives also used to organise exhibitions and promote their artistic tendencies characterised by the revitalisation of art and new approaches for the interpretation of well-known themes according to the technological and scientific accomplishments of the time. As a movement that emerged as an immediate reaction to the Academy's historicist artistic principles, Jugendstil attracted more modern artists who willingly embraced ornamental painting. They wanted to compete against conservative art and launch stricter quality requirements independent of the audience's taste.

In such an environment and artistic pluralism of Munich, Franz von Stuck is formed. He was born in Lower Bavaria but early moved to Munich where he received his education first at the School of Applied Arts and then at the Academy of Fine Arts. ${ }^{2}$ However, after

${ }^{2}$ Franz von Stuck was born in 1863 . He worked as an illustrator, a designer, and occasionally as a cartoonist in a Munich newspaper, after formal education. 
formal education, Stuck turned to his ideas. As a professor of composition in art at the Munich Academy, his position allowed him to transfer those ideas to countless students and followers. Consequently, he paved the way for German Modernism. Munich's turbulent art scene provided a variety of techniques, media, and visual repertoire that Franz von Stuck used. In such an environment, the artist could choose from different influences, styles, and ideas that he would try to reconcile, balance, and perfect in the making of his villa.

Seemingly irreconcilable features of Stuck's character and art gained its final multimedia expression with Villa Stuck's construction. Using elements of different well-known art movements (Secession, Symbolism, Academism, Classicism, etc.), Franz von Stuck approached the monumental solo endeavour to design his residency. The villa was designed to reflect von Stuck's understanding of timeless truths, universal human feelings, and worries. The artist's position in the centre of such a semi-mythical space should have reconciled the ambivalence between the modern period and the desire for regression in ancient times. Having accepted the collective social contradictions, dilemmas, and worries of the time, when creating his villa, Stuck categorically refused to decide between the past and the present, the Apollonian and the Dionysian, the rational and the natural (DANZKER 2013: 24).

Construction of the villa began in 1897 . Between 1898 and 1909, the building underwent several transformations primarily of the façade. However, they did not seriously disturb the original concept. There are many possibilities to analyse various stylistic and ideological features of Villa Stuck. Still, for the sake of our research, the focus will be on its Antique features, i.e. Stuck's vision of Classical Antiquity strengthened by the reawakened interest in the Old Age noticeable with many artists and intellectuals in the late $19^{\text {th }}$ century. From the first glance at the Neoclassical façade (Fig. 2) decorated with copies of Antique statues, through the furniture resembling those in ancient Roman villas, all the way to the smallest stucco details, everything reveals references to the Classical Antiquity. It is inseparably linked with Stuck's interpretation of Classical Antiquity as an essentially similar period to his contemporary era and the centre of eternal human essence and internal conflicts. The all-encompassing permeation of Antique elements is even more noticeable in the Villa's interior wherein richly decorated walls, ceilings, and rooms are filled with Stuck's paintings and sculptures (Fig. 3). The entire villa is a physical embodiment of the artist's restless nature and a stage for his creative expression.

Still, the villa's unique Music Room stands out from the courtyard, entrance porch, library, Stuck's atelier, reception hall, lobby, and private rooms. The Music Room interior is filled with pseudo-Antique elements that the artist accumulates in an unusual circularly shaped area. Each of its elements can be related to Stuck's perception of Classical Antiquity or borrowed interpretations by his contemporaries and like-minded people.

Above all, it is important to highlight the almost exact ideological connection between the entire Stuck's design of the Music Salon modelled after Classical Antique vitality and the new scientific interpretation of ancient Greek man constantly torn between two intertwined artistic and creative principles as described in The Birth of Tragedy by Friedrich Nietzsche, that was published originally in 1872 (Husslein-ArCO, KLEE 2016: 91). 


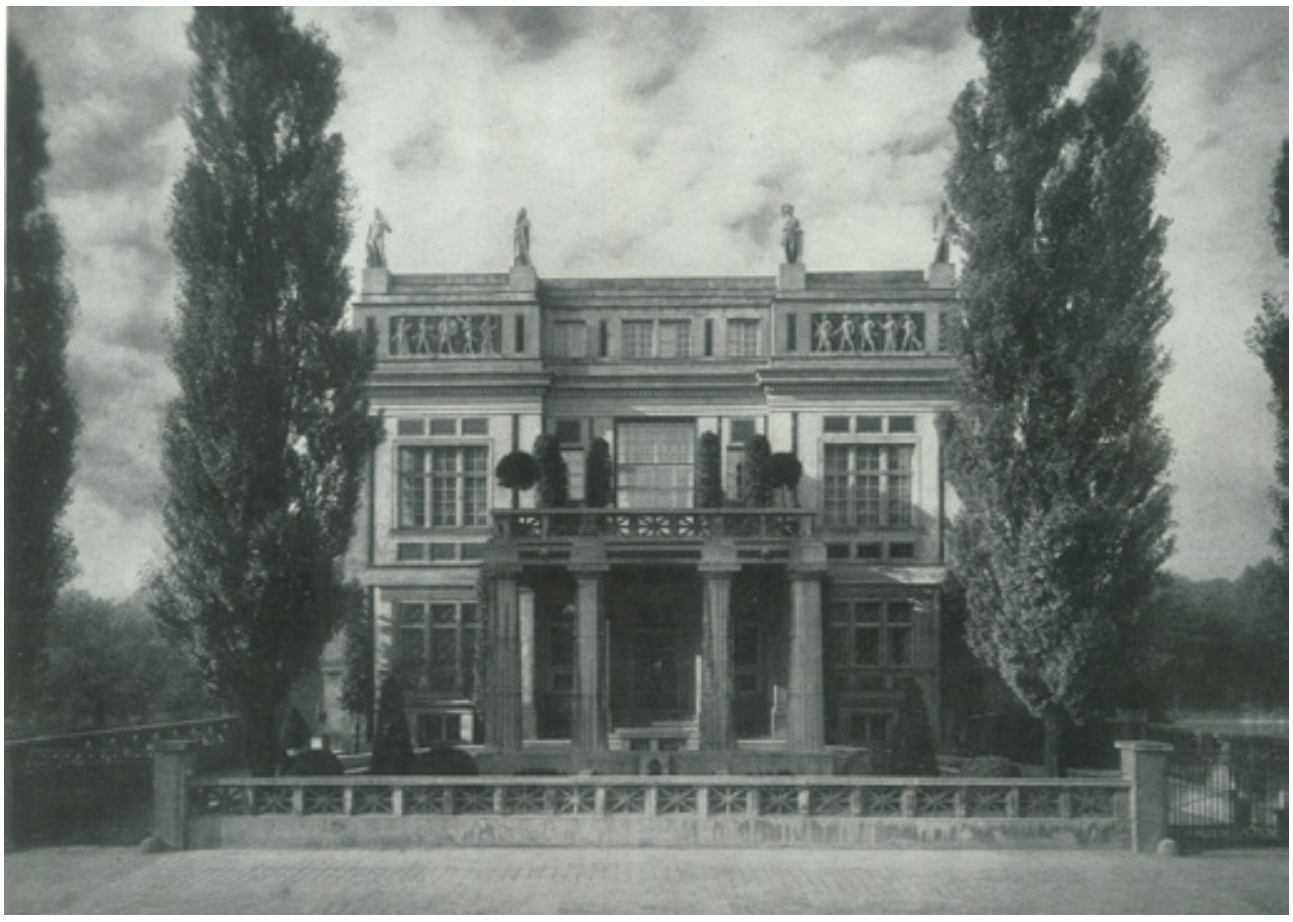

Fig. 2. Main facade of Villa Stuck, photography, source: Ostini, Fritz. Villa Franz von Stuck, Munchen, Darmstadt: Verlagsanstalt Alexander Koch, 1909, 3.

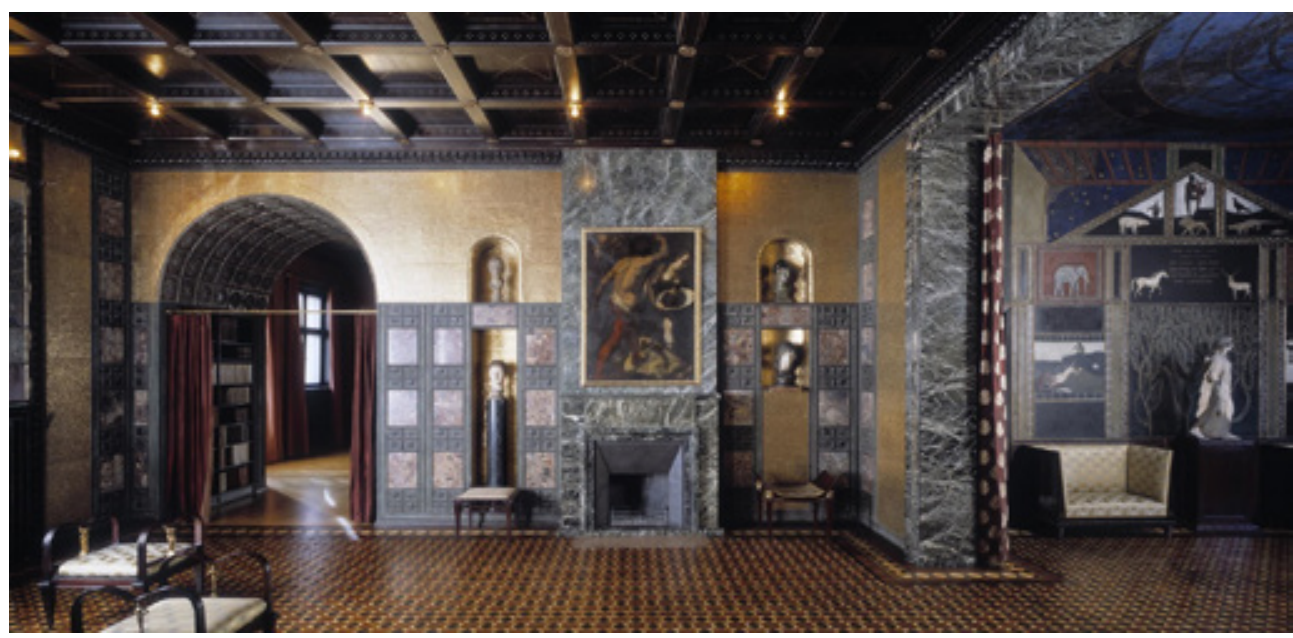

Fig. 3. Interior of Villa Stuck with a view of the Reception Room and the Music Salon, photography, August Lorenz, 1898, Museum Villa Stuck, source: Brandlhuber, Margot Th. Michael Buhrs (ed.). Im Tempel des ich - das künstlerhaus als Gesamtunstwerk Europa und Amerika 1800-1948, Museum Villa Stuck München: Hatje Cantz Verlag, 2013, 189. 
In his revolutionary literary work, Nietzsche presents the hypothesis of the duality of the Apollonian and the Dionysian as a constitutive element of the Hellenes, which fosters people to create. Furthermore, Nietzsche describes the Greek god Apollo as a form and clarity paradigm, a dream interpreter and a beacon of individuality, harmony, form, intellectual imagination, and norm. He is also the god of creative artistic forces and an inventive creator. (Ниче 1960: 21). In contrast, Dionysus represents a sensual, expressive, spontaneous and savage nature, the personification of excess, chaos, disharmonious ecstatic dance and collectivity. Nietzsche considered Dionysus' action as a state of intoxication and constant metamorphoses turning into a new form. If Apollo is a metaphor and inspiration for the fine arts, Dionysus rules the realm of music. Trying to implement personal artistic expression in a room that glorifies music and dance, Stuck, like Nietzsche, confronts two artistic aspects attributed to the archetypal couple's poles. From the initial pages of The Birth of Tragedy, there is an obvious similarity between Nietzsche's ideas and Stuck's artistic expression and the expressions of many other artists inspired by the new understanding of Classical Antiquity. However, having permeated the Munich villa (and the Music Salon in particular) with the Apollonian form and Dionysian subject matters, Stuck seems to have accepted Nietzsche's theory more literally than his contemporaries and colleagues. Hence, he provided a personal architectural, sculptural, and painterly response. The similarity of Classical Antiquity receptions by two prominent Germans - Nietzsche and Stuck, has been noticed in the existing scientific literature. Still, it is most often considered concerning Stuck's Symbolist painting, but not with the Villa Stuck's design or its Music Salon.

We will have achieved much for the study of aesthetics when we come, not merely to a logical understanding, but also to the immediately certain apprehension of the fact that the further development of art is bound up with the duality of the Apollonian and the Dionysian, just as reproduction depends upon the duality of the sexes, their continuing strife and only periodically occurring reconciliation. (НИЧЕ 1960: 19)

Considering these lines of Nietzsche, the seeming incoherence of the Music Salon's decorative programme of Villa Stuck takes on a new interpretation. It visually refers to the duality, constant permeation, transformation, and struggle for supremacy between the two principles which Nietzsche described as forces of the Hellenes and psychology later confirmed as timeless and omnipresent archetypal principles.

Two aspects of the human psyche, the Apollonian, which is harmonious and orderly, and the Dionysian, which is unrestrained and changeable, are always in a clash within Stuck's personality. Therefore, this duality will be Stuck's most enduring preoccupation in his entire opus. Villa Stuck incorporates harmonious proportions based on the golden ratio as an eternal aspiration to follow Apollo's artistic precision and soberness, and the paintings of melted forms, expressive colours, and overflowing energy. It reveals Stuck's familiarity with contemporary philosophy and his attempt to reconcile the two extremes to present himself as an all-encompassing, transcendental artistic figure that rises above exclusivity. There is an apparent Dionysian principle in the Music Salon, perhaps to a greater extent than 
in the rest of the Villa Stuck. It is noticeable not only in its name, purpose, and the fact that Dionysus is primarily associated with the music, dance, and ecstatic movement, but also in the entire painted and sculpted repertoire. In the Music Salon, Stuck tried to evoke the allegorical-mythical environment of the primordial carefree intoxication with music as a way of drowning into collectivist and primal states of creative potential. A little further in The Birth of Tragedy, Nietzsche wrote:

Let no one try to detract from our belief in a still imminent rebirth of Hellenic Antiquity, for that's the only place where we find our hope for renewal and reformation of the German spirit through the fiery magic of music. (НИЧЕ 1960: 106)

Once again, with his concept of the Music Salon, Franz von Stuck shares Nietzsche's optimism for Antiquity's rebirth (or at least its individual features) to fulfil the cultural mission. Having recreated the then-known Greek poetry elements or their interpretation by Nietzsche, Stuck used complex symbolic and visual language to shape a room-stage within his home dedicated to eternal music values, thus paid homage to their substitute and primordial initiator - Dionysus.

We should not exclude by no means the influence of Stuck's contemporary, the psychologist Sigmund Freud, to the villa and the Music Salon's design. His observations of human behaviour patterns have largely influenced a paradigm change in the reception of Classical Antiquity and shifted the focus from classical academic aesthetics and understandings of Antiquity to the idiom of vitality and repertoire of human passions equally present in early primitive societies as in the late $19^{\text {th }}$ century (DANZKER 2013: 49-50). Stuck's dealing with the archetypes of Classical Antiquity is closely related to Freud's passion for the ancient period, which directly influenced his new understanding of the human psyche the so-called "archaeology of the unconscious". Freud's observations about early humans' "savage" mentality are in line with Stuck's visualisations of "the oldest and darkest beginnings of humanity." If Freud was the first to sense the repressed unconscious' undiscovered proportions, Stuck materialised the same by visual means.

The Antique aura of the Music Salon is further reflected in Stuck's sculpture of the goddess Pallas Athena, theatrically positioned behind a curtain and flanked by two noticeably decorated marble pillars. Her identification is facilitated both by the inscription above the statue and all the known iconographic elements that accompany the goddess, such as the painted owl, a symbol of wisdom, and the olive branch, a truce symbol. Like most motives from the Music Salon of Villa Stuck, Athena did not appear in the artist's opus for the first time. In his oeuvre, it was a recurring figure reproduced countless times as a paradigmatic motive of the Munich Art Nouveau whose co-founder was Stuck. Thus, before the Music Salon was adorned with the full-size statue of Pallas Athena, Stuck used it for posters for the exhibition of Munich Art Nouveau Artists in 1897 and 1988, and his numerous artworks from the same period. Athena Pallas from the Music Salon is the peak of Stuck's years-long artistic experiments with the motive of the ancient Greek goddess. Considering the $19^{\text {th }}$-century paradox of understanding a woman as both the embodiment 
of lovely innocence and a dangerous femme fatale, the choice of Pallas Athena for the $\mathrm{Mu}-$ sic Salon becomes more understandable. Consistent with Stuck's opus, villa, and Music Salon's conceptual polarity, his Athena is another conveyor of double meaning, understood simultaneously as a ruthless warrioress and a wise counsellor. Therefore, it can be assumed that Stuck set this sculpture in the Music Salon to contrast it to his presence and an abundance of primitive, lustful, and, above all, masculine energy, embodied in the form of numerous figures of Pan, a slightly mitigated version of the intoxicated Dionysian state and an archaic form of sexual and creative instinct. Like the previously mentioned relationship between the Apollonian and the Dionysian which permeate, struggle, and reconcile periodically creating at that moment the artistic sublimity, the sculpture of Pallas Athena can be interpreted in the light of Stuck's personal artistic or universal musical need for a female figure (a muse) as a personification of inspiration and quest for the lost totality through the union of opposite sexes.

Franz von Stuck personally painted all the Music Salon walls referring consciously to the then rediscovered Pompeian wall painting. Although archaeological excavations in Pompeii and Herculaneum began several centuries before Stuck, the discoveries of these Roman cities destroyed by Mount Vesuvius's eruption became available to the general public for the first time in the period when he was building his villa. It was when Europe became acquainted with the material remains of ancient Roman society and its achievements in arts. Unlike earlier semi-fantastic and imaginative interpretations, this phase of Classical Antiquity research provided new interpretations and views supported by Ancient Rome's archaeological findings. Thanks to August Mau, who then took the lead in Pompeian examines, these discoveries became the world-known (DoBBINS, Foss 2007: 27-35). Mau's work, partly because of his systematic approach, coherent writing style, and clarity of expression, and partly because of his studies' translation into many languages, secured his world fame promoting him a key figure of the $19^{\text {th }}$-century archaeology and the most outstanding expert when it comes to Pompeii. His classification of four styles of Pompeian wall painting revived the interest of many painters to understand the artistic view of the Ancient Romans. The remarkable similarity of some Neapolitan frescoes and wall paintings of the Villa Stuck Music Salon points out that Franz von Stuck was familiar with Mau's work (Fig. 4; Fig. 5). For instance, Stuck's Music Salon paintings closely resemble the wall paintings of the villa in Boscoreale. These similarities are reflected in Stuck's interpretation of the fourth Pompeian painting style which August Mau defined as a combination of the second and the third, that is, a combination of architectural and mythological motives in the villas' interiors. Overall, Villa Stuck has many elements of the villa described by Pliny. Still, the Music Salon walls most consistently reflect Stuck's fascination with ancient Roman wall painting subject matters. The abundant use of red and blue colours in the Music Salon wall decorations and the painted architectural elements make the viewer get lost in the illusionistic depth and the painted landscapes. Here we should have in mind the enormous importance that Stuck, as the protagonist of Symbolism, credited to colour as a poetics value based on the spiritual 


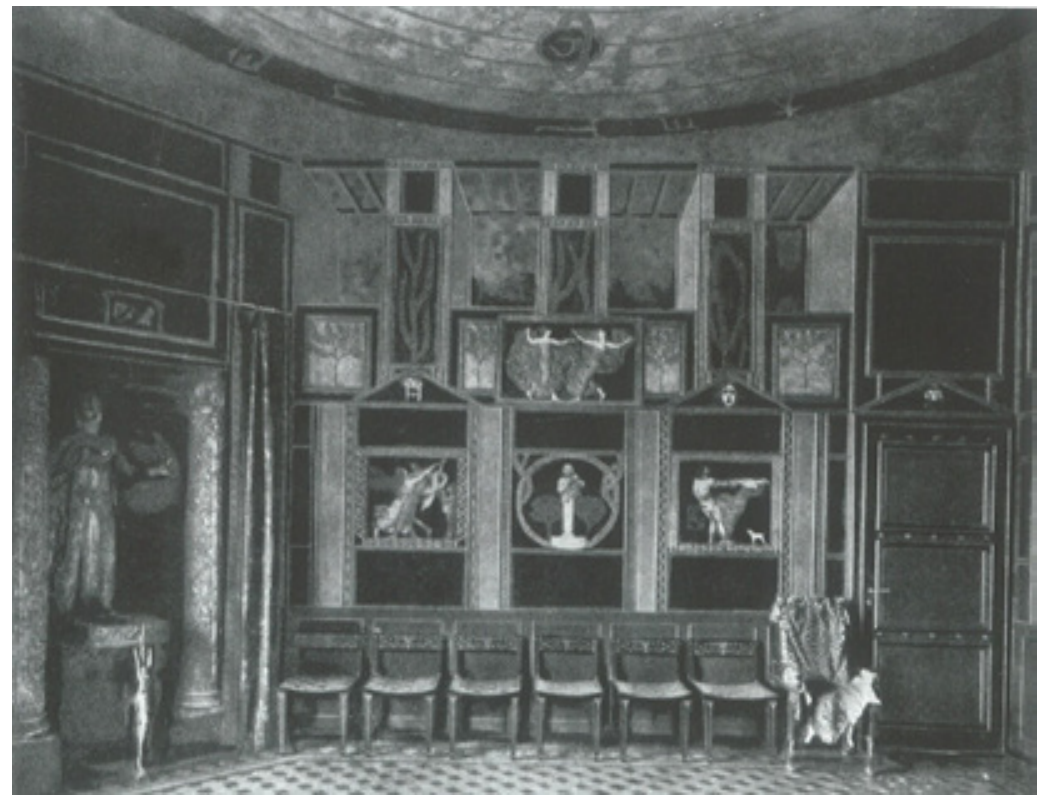

Fig. 4. The wall of the Villa Stuck Music Salon with the images of dancers and Pan, photography, source: Mendgen, Eva. Franz von Stuck 1863-1928 -

Ein Fürst im Reiche der Kunst, Köln: Benedikt Taschen Verlag, 1994, 35.

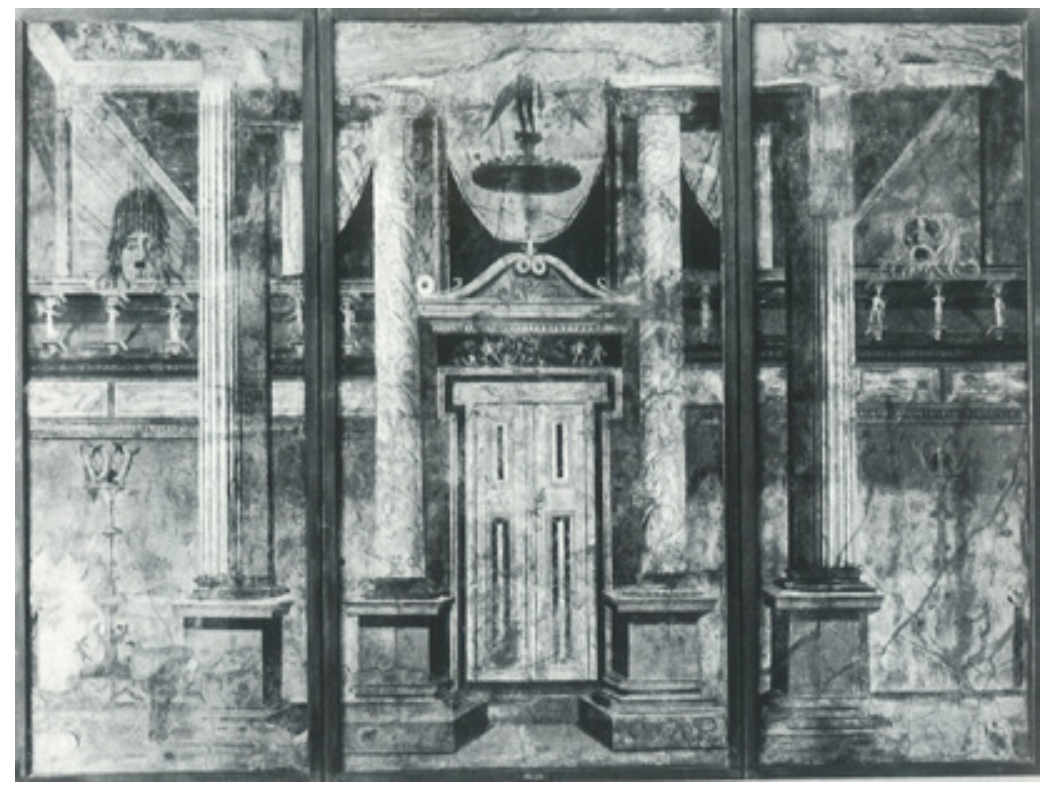

Fig. 5. The wall in Villa in Boscoreale, Naples, around 50 B.C. photography, source: Zajder, Rihard. Rimsko slikarstvo, Beograd: Jugoslovenska revija, 1976, 23. 
content (БОРОЗАН 2018: 83). The seeming depth of the Music Room painted architecture is enriched with square and circular fields. With the Romans, they were reserved for presentation of mythological scenes and cycles, exclusively, but Stuck added figures of dynamic and dramatic dancers and Pan in the centre.

The thematic repertoire of carefree entertainment, frantic movement, and swirling draperies was fitted into the rest of the room decoration and Stuck's idea of a Dionysian musical dissonance. The artist gave his personal conceptual favourites the rank of religion or mythology. Besides inserting vital and arcadian subject matters in place of mythological images, Stuck's also made pseudo-antique altars wherein he placed his images of an erotic and psychologising character. Like Athena, we will often find the dancers and Pan in Stuck's sculptures and paintings. Those were among his favourite motives and formed the core of his mythology. Furthermore, the presented winding dance visualised the power of music as the most abstract medium (БОРОЗАН 2018: 79). Numerous dance studies and similar variations of the same theme made in different media are essential for understanding Stuck's most enduring artistic preoccupation throughout his artistic career. Their presence in the Villa's wall decoration illustrates Stuck's return to Classical Antique figures and subject matters and how he enhanced them for the Music Salon decoration. Pan, the Greco-Roman god of herd and hunting, Dionysus' companion and half-animal being, had been considered a provocateur of lustful Satyrs since Antiquity (СРејОвИћ, ЦЕРмАновић 1989: 317-318) and like them, the personification of animal instinct and intoxicated and unrestrained behaviour fostered by the Dionysus. According to the myth, Pan wanders mountain peaks, rocky paths, and forests hunting beasts or playing his instrument - syrinx. He is often in the company of Dionysus and his companions, nymphs and maenads; he loves the dance, provides a successful hunt, and also possessed the prophetic gift that he passed on to Apollo. Pan is unquestionably the most prominent mythical figure in Stuck's entire oeuvre, which testifies to the god of nature's then popularity and its appearance within many contemporary artists' paintings and cycles. Stuck's choice of Pan for the Munich magazine cover of the same name supports this claim. Franz von Stuck was a founder and an illustrator of the Pan magazine published between 1895 and 1900. The artist was often identified with Pan or Satyr, which is evident in the frequent presence of Pan in his paintings, sculptures, and the hybrid portraits where the artist and Pan were merged into one image. His fascination with mythical creatures, half-humans, half-animals, Centaurs, and Satyrs, reflects Stuck's interest in the eternal conflict of animal and rational human nature, but also in the state of mind of $19^{\text {th }}$-century man during the crisis of sexuality and the shift in the biological understanding of species the most clearly detected in Darwin's theory of evolution which also coincides with the time of Stuck.

On the wall across from the dancers and Pan, there is a painted architectural frame that Stuck shaped to allude to the façade of the ancient temple, which once again confirms that this room was designed as a kind of temple dedicated to music, dance, rhythm, and melody. Consistent with the previously mentioned dichotomies bestial-rational, orderlychaotic, tame-wild, controlled-explosive and other contradictions presented in the room 
forming the core of Stuck's understanding of Classical Antiquity as an ideal Golden Age of human history (wherein such opposites and their rivalry considered an integral part of the heroic struggle with own contradictions), there is Orpheus at the top of the composition (Fig. 6). Orpheus is an antipode of Pan and a creator of Apollo's divine music. Orpheus is

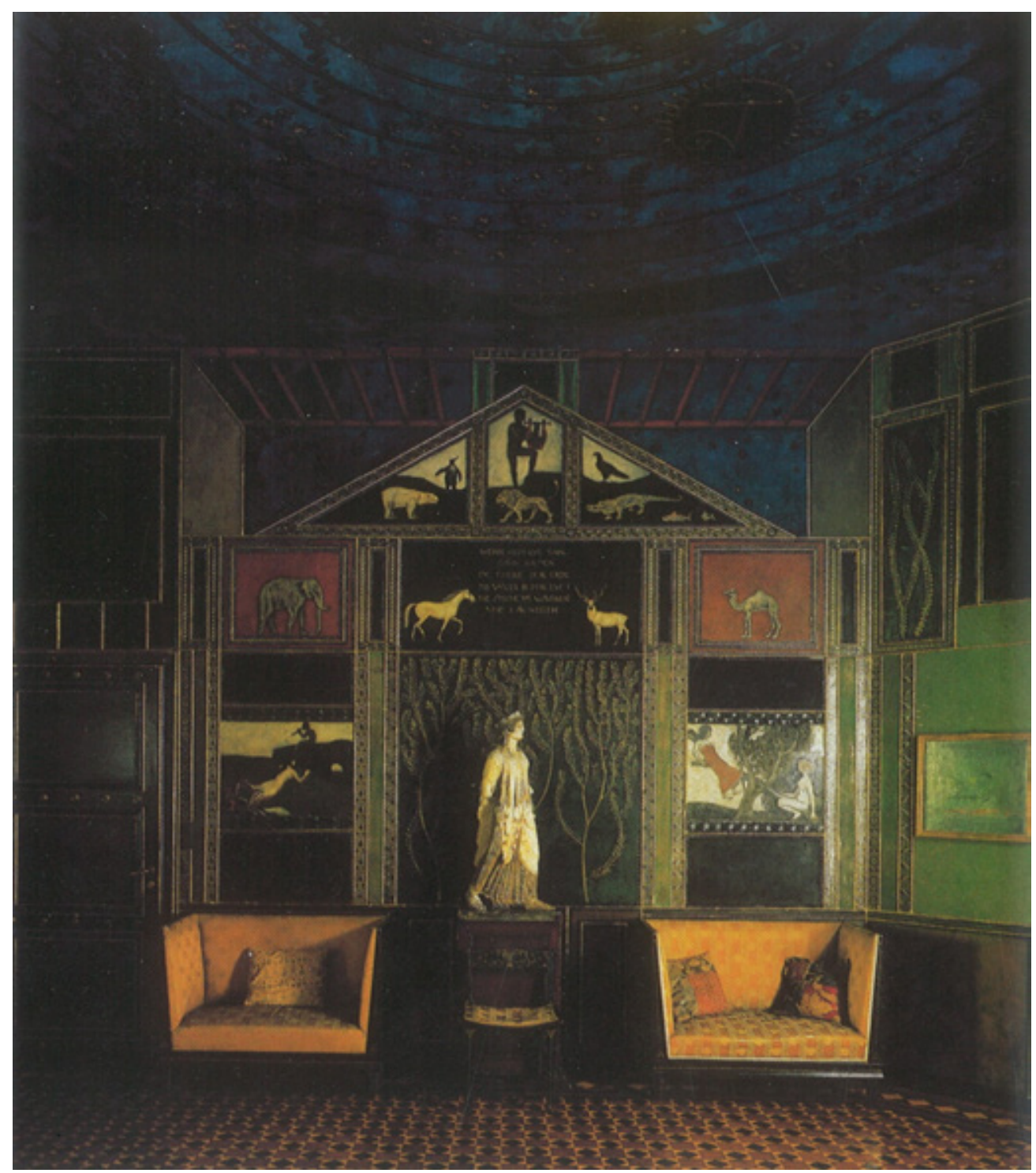

Fig. 6 . The Villa Stuck Music Salon, the wall with Orpheus and animals, photography, source: Brandlhuber, Margot Th., Michael Buhrs (ed.). Im Tempel des ich - das künstlerhaus als Gesamtunstwerk Europa und Amerika 180o-1948, Museum Villa Stuck München: Hatje Cantz Verlag, 2013, 191. 
the most famous mythical singer, musician, and poet, and according to myth, Apollo ${ }^{3}$ himself taught him these skills (СРЕјОвИЋ, ЦЕРмАНовИЋ 1989: 310-312). He plays the lyre in honour of the muses, and the power of his song and music was considered miraculous. When he sings, flocks of birds circle his head, fish jump out of the sea, rivers stop their flows, mountains tremble, and all the animals gather at his feet to hear the divine song. Around the figure of Orpheus in the Music Room, there is a variety of animals approaching him in hopes of enjoying the music of his lyre. Stuck decided to paint the crucial point of the myth of Orpheus, portraying him when playing the lyre to emphasise the potency and power of music, but this time not seductive, lustful, and satyric, but loving, tender, and soothing. Orpheus is the total opposite of Pan. Pan has a grotesque appearance. He frightens nymphs, menades, and nereids. In contrast, Orpheus is a handsome young man who resembles Apollo. He is successful in love and enchants nymphs. Pan plays the syrinx or flute to the rhythm of intoxicated bacchanalian music, and Orpheus plays his lyre with which he captivates hearts and tames animals. These two cycles of the Music Salon, perhaps the best of all the elements mentioned above, confirm Stuck's idea of a dual understanding of music and the permeation of entire room with the principles of both Nietzsche's deity principles.

Although the concept of a total work of art (Gesamtkunstwerk) is often attributed to the great $19^{\text {th }}$-century musician Richard Wagner who used the term in his 1849 work The Artwork of the Future, the similar ideas were shared among philosophers and revolutionaries a little earlier (FRISCH 2005: 92). Important precursors of such ideas in the German cultural sphere were Philipp Otto Runge and Moritz von Schwind with their art and theory of the early $19^{\text {th }}$ century. It is important to mention their efforts to introduce a music feature in their paintings. Yet these ideas culminate in Wagner's work wherein he outlined the basics. Thus, Wagner established the characterisation of a type of modern art that he hoped to bridge the artistic fragmentation and unite various art types that gradually moved away from the original state of closeness known only to ancient societies. The magnificent artistic expression of the ancient people was understood as a reflection of the harmony between thought and action and an equally enthusiastic approach to artistic production and all other life segments. The idea of a total work of art had a significant influence on German art, and Franz von Stuck was another advocate of its ideals. The Munich Art Nouveau, of which Stuck was a pioneer, relies on the groundworks of a total work of art and the idea of creating a complete style that would nullify the boundaries between the high and the applied art. According to the Munich Art Nouveau and Wagner's Gesamtkunstwerk, life itself would represent the total art that unites architecture, painting, and the design of everyday items. The idea of artistic unity embraced by the late $19^{\text {th }}$-century German art circles is nowhere more apparent than in the Music Room of Villa Stuck. Being the architect, painter, sculptor, and designer of his Munich villa and dealing throughout his life with photography, illustration, graphics, and book design, Franz von Stuck holds an important place in the tradition of ideas of total art that marked all aspects of his life. The idea of total artwork began in England with the Morris' Arts and Crafts movement and Ruskin's fiery commitment to

\footnotetext{
${ }^{3}$ According to some versions of the myth, Apollo is Orpheus' father.
} 
renew traditional crafts to revive society. It culminated in comprehensive treatment and study of the arts by the German Bauhaus.

As another example of consistent adherence to the total artwork principles (which at the same time testifies to Stuck's broad education and attention to the smallest detail), the Music Salon emphasises the uniqueness and authenticity of Franz von Stuck's art. In its totality, Villa Stuck in Munich is the finale of the artist's many years of experiments with the leading artistic currents of his time and his intellectual efforts to perfect his concept painting ideas. When designing the villa and its interior, Franz von Stuck employed all possible knowledge and means to create a private utopia using various Classical Antiquity topoi and artistic interpretations. However, in the Music Salon, there is a pronounced aestheticisation of the space employing Stuck's abilities to its utmost. Designed as a temple of music and revived by the synesthesia of architecture, painting, and sculpture, the Music Salon holds a special place in the villa, Stuck's opus, and German art at the break of the $20^{\text {th }}$ century. Carefully and thoughtfully choosing the visual repertoire and narrative to incorporate into his private temple of music, the artist designed a multi-function room. On the one hand, it is a mythical, archaic, Antique space wherein musical harmony reigns, which is achieved through the Apollonian and the Dionysian fusion. On the other, it is a careful revitalisation of the narratives of Classical Antique mythology. Additionally, it is an extension of Stuck's personality, torn between academic aesthetics and subjective Symbolist vision, between his status as a respected and prominent figure in society and his need for extravagance and dramatic presentation, between finally finding his artistic expression and innovative nature. Villa Stuck still exists today and is transformed into a museum. The transformation preserved perhaps the most complex Stuck's artwork which stands as a reminder of the artist's successful fusion of many elements and ideological models and his effort to provide a pseudo-Antique space with the special and unique appearance. Interpretation of the Music Salon through Stuck's vision of Classical Antiquity is just one of the possible approaches for understanding its value and place in art history. However, the complexity of villa requires further analysis and other approaches to Stuck's art, confirming the necessity for researchers to be open to various phenomena to illuminate the layers of meaning, original and subsequent accurately.

\section{LITERATURE}

BernheImer, Charles. Decadent Subjects - The Idea of Decadence in Art, Literature, Philosophy, and Culture of the Fin de Siecle in Europe. Baltimore, USA: The John Hopkins University Press, 2002.

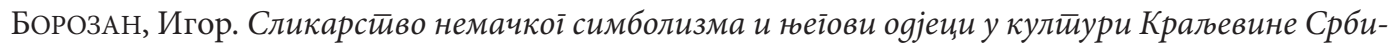
je. Београд: Универзитет у Београду - Филозофски факултет (BoROzAN, Igor. Slikarstvo nemačkog simbolizma i njegovi odjeci u kulturi Kraljevine Srbije. Beograd: Univerzitet u Beogradu - Filozofski fakultet), 2018. 
RECEPTION OF CLASSICAL ANTIQUITY: A CASE STUDY OF THE MUSIC SALON OF VILLA STUCK...

BRANDlHUBER, Margot Th., Michael Buhrs (ed.). Im Tempel des ich - das künstlerhaus als Gesamtunstwerk Europa und Amerika 180o-1948. Museum Villa Stuck München: Hatje Cantz Verlag, 2013.

BRANDlhuber, Margot Th., Michael Buhrs (ed.). Franz von Stuck - Meisterwerke der Malerei, (eine Ausstellung des Museums Villa Stuck, Munchen, 4. Dezember 2008 - 15. März 2009). Munchen, Deutschland: Hirmer Verlag

БуркХАРт, Јакоб. Повести ірчке кулитуре, I-IV, Сремски Карловци - Нови Сад: Издавачка књижарница Зорана Стојановића (BURкнавт, Jakob. Povest grčke kulture, I-IV, Sremski Karlovci - Novi Sad: Izdavačka knjižarnica Zorana Stojanovića), 1992-1993.

Williamson, George S. The Longing for Myth in Germany - Religion and Aesthetic Culture from Romanticism to Nietzsche. Chicago and London: University of Chicago Press, 2004.

DANZKER, Jo-Anne Birnie (ed.) Franz von Stuck, (cataloque of the exibition Franz von Stuck at the Frye Art Museum, Seattle USA, November 2, 2013 - February 2, 2014.) Seattle, USA.

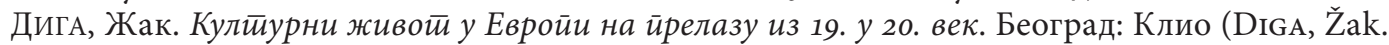
Kulturni život u Evropi na prelazu iz 19. u 20. vek. Beograd: Klio), 2007.

DobBIns, John J., Pedar W. Foss (ed.). The World of Pompeii. Routledge New York: Taylor and Francis Group, 2007.

EHRHARDT, Ingrid, Simon Reynolds. Kingdom of the Soul - Symbolist Art in Germany 1870-1920. Munich - London - New York: Prestel Publishing, 2000.

ЗАјдеР, Рихард. Римско сликарстиво. Београд: Југословенска ревија (ZAJder, Rihard. Rimsko slikarstvo. Beograd: Jugoslovenska revija), 1976.

ЛЕНЦ, Кристијан, Вероника Шредер (ур.) Минхенска школа 1850-19оо, Изложба слика из Баварских gржавних збирки слика и gруіих музеја. Београд: Народни музеј (Lenc, Kristijan, Veronika Šreder (ur.) Minhenska škola 1850-190o, Izložba slika iz Bavarskih državnih zbirki slika i drugih muzeja. Beograd: Narodni muzej), 1988.

MaU, August. Geschichte der dekorativen Wandmalerei im Pompeji. Leipzig, 1882.

MENDGEN, Eva. Franz von Stuck 1863-1928 - Ein Fürst im Reiche der Kunst. Köln: Benedikt Taschen Verlag, 1994.

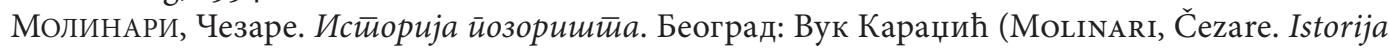
pozorišta. Beograd: Vuk Karadžić), 1982.

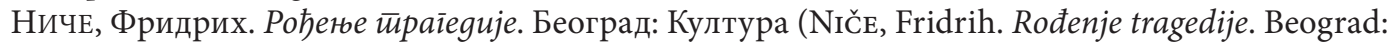
Kultura), 1960.

Ниче, Фридрих. Случај Ваїнер. Београд: Графос (NičE, Fridrih. Slučaj Vagner. Beograd: Grafos), 1988.

Ostini, Fritz. Villa Franz von Stuck, Munchen. Darmstadt: Verlagsanstalt Alexander Koch.

Срејовић, Драгослав, Александрина Цермановић. Речник ірчке и римске митиолоіије. Београд: Српска књижевна задруга (SREjović, Dragoslav, Aleksandrina Cermanović. Rečnik grčke i rimske mitologije. Beograd: Srpska književna zadruga), 1989.

FACOS, Michelle. Symbolist Art in Context. Berkley - Los Angeles, London: University of California Press, 2009.

VON STIELER, Eugen. Die Königliche Akademie der bildenden Künste zu München, Festschrift zur hundertjahrfeier. Munich: Bruckmann, 1909.

FRISCH, Walter. German Modernism - music and the arts. Barkley - Los Angeles, London: University of California Press, 2005.

Funrmeister, Christian, Hubertus Kohle, Veerle Thielemans (ed.). American Artists in Munich - Artistic Migration and Cultural Exchange Processes. Berlin Munchen: Deutscher Kunstverlag, 2007. 
Hofmann, Werner The Earthly Paradise - Art in the Nineteenth Century. New York: George Braziller, 1961.

Husslein-Arco, Agnes, Alexander Klee (ed.). Sin and Secession - Franz von Stuck in Wien. Wien: Belvedere, 2016.

Огњен Д. Минић

\section{РЕЦЕПЦИЈА АНТИКЕ НА ПРИМЕРУ МУЗИЧКОГ САЛОНА ВИЛЕ ШТУК У МИНХЕНУ}

\section{Резиме}

Цитирање античких топоса и елемената у изградњи приватних вила установљено је као пракса још од давнина. Ипак, не постоје два истоветна приватна простора која реферишу на идентичне аспекте античког периода. Вила Штук у Минхену, уобличена према замисли великана немачке уметности Франца фон Штука, пружа интересантан увид у поимање античког човека и уметности од стране немачког културног круга са краја XIX и почетка XX века. Вила Штук и, посебно, Музички салон унутар ње, сведоче о Штуковој рецепцији антике, позиционираној између материјалних доказа и субјективне визије. Користећи се револуционарним открићима о тековинама античких друштава на пољима филозофије и археологије и придодајући им сопствени уметнички израз, Франц фон Штук креира вилу Штук, која представља можда најкомплексније мултимедијално дело његовог опуса.

Кључне речи: Франц фон Штук, вила Штук, антика, рецепција антике, Музички салон. 